Kobelinsky, Carolina (2020). Border Beings. Present Absences among Migrants in the Spanish Enclave of Melilla, Death Studies, 44(11): 709- 717.

Abstract: Death is a constant feature of lives lived at the borders for migrants trying to reach Europe without the necessary authorizations from nation-states. At the border between Melilla and Morocco, many stories are told about near death experiences during attempts to cross both land and maritime borders, as well as about abandoned bodies. Other common narratives focus on the living dead, on the missing presumed dead, on unidentified bodies, and on the living who continue to be haunted by the disappeared. Drawing on ethnographic material, this paper examines the ways in which migrants' journeys and subjectivities are shaped by death on the migrant trail to Europe.

Key words: EU borders - migrants - dead bodies - the disappeared - ghosts - the living dead.

Nine bodies were found on the shores of Los Lances Beach in Tarifa, on November 1, 1988. They are the first in a long list of border deaths. ${ }^{1}$ For 30 years, migrants have been dying at the European borders but the issue has only become widely publicized since the shipwrecks on the Lampedusa coast in October 2013. Border deaths are now regular occurrences in the Mediterranean and the Aegean Sea. Numerous research studies - but also investigations carried out by journalists and NGOs - have shown that these deaths are a direct effect of hardline securitization policies and techniques of migration control (Albahari, 2015; Babels, 2017; Weber \& Pickering, 2011). I will not dwell here on this form of European sovereignty, expressed in the power to expose people to the risk of death and, incidentally, to allow people to continue living despite being unwanted. Inspired by Foucault's concept of biopolitics (Foucault, 1978, 2009, 2010) and Achille Mbembe's explorations of necropolitics (Mbembe, 2003), existing scholarship on European Union (EU) border deaths has examined the policies and practices that lead to a form of government through death (Topak, 2014; Rygiel, 2016; Squire, 2016). Instead, I will focus on the impact that these border deaths have on life.

Death is a constant feature in lives at the borders for those trying to reach Europe without the necessary authorizations from nation-states: it is a possible eventuality, a material reality, and a ghostly presence. At the land border between the enclave of Melilla and the Moroccan province of Nador, death is ubiquitous even though, unlike at sea borders, few attempts have been made to count the number of deaths and few bodies have been found near the fences that embody the EU-Africa boundary. There are many stories told in the first person about near death experiences while attempting to cross both land and maritime borders, and about abandoned dead bodies. Other common narratives focus on the living dead and their efforts to resist death, on the missing presumed dead, on unidentified bodies, and on the living individuals who continue to be haunted by the dead or by the disappeared. Together, all these accounts trace an outline of the different forms taken at the border by the "disappeared in a liberal regime" (Tassin, 2010).

Drawing on ethnographic material, this article examines the ways in which migrants' journeys, experiences, and subjectivities are affected and shaped by death on the migrant trail to Europe. The data was collected between 2014 and 2018 among border-crossers during fieldwork carried

\footnotetext{
${ }^{1}$ Compiled by Gabriele del Grande, an Italian journalist who was one of the first to count deaths at the borders. His blog: http://fortresseurope.blogspot.com/p/la-fortezza.html
} 
out in the enclave of Melilla ${ }^{2}$ and its Moroccan surroundings, as well as on the Spanish mainland and in France. Most of my interlocutors were men from West African countries aged between 18 and $35 .{ }^{3}$ As a woman among men much younger than myself, I soon had access to narratives provided by a number of interlocutors that moved beyond macho representations of the male migrant overcoming the extreme challenge of border crossing. In the accounts they gave during our conversations, they emphasized their vulnerability without presenting themselves as victims, and this made it possible quite quickly to engage in more personal discussions with some of them about their perceptions and experiences. These exchanges mainly took place in French, which was not their mother tongue but was the language they used to communicate with one another. Among border-crossers, this common language is also embellished with terms from various languages used to refer to objects, individuals, and actions specific to their life as migrants. There is therefore a shared vocabulary of the border that borrows terms or expressions from Wolof, Fulani, Nouchi (Ivorian slang), Spanish, and Arabic.

This article deals with the various ways in which people negotiate the disruption caused by the deadly nature of the borders in question and the many deaths with which they are confronted while crossing them. It also looks at the ways in which border crossers relate to the dead and the disappeared. Border deaths can be considered "critical events" (Das, 1995, p. 6): although they are disruptive, these deaths are also normalized in ordinary life, producing new modes of action and redefining traditional categories. After border deaths, new beings - and new forms of being - emerge and engage in collective life. Many of these entities, which I refer to as "border beings", come up in the narratives of the people I met at the border, and exist in very real ways. Although they are not necessarily physically embodied or properly tangible, they account for particular forms of human existence, provide a condensed version of lived experience, and are therefore nevertheless sufficiently perceptible to my interlocutors to be taken seriously by them. In the following pages, I document small-scale exchanges about border deaths with a view to exploring how different border beings - disappeared migrants, unidentified bodies, migrants known to be dead, the living dead, and the living - all co-exist at the border. By exploring the forms taken by this cohabitation, I make the assumption that it is possible to reach an ethnographic understanding of the aesthetic regime, in Jacques Rancière's sense of the term (2004), at the core of contemporary border politics: an aesthetic regime that is a delimitation of spaces and times, of the visible and the invisible, of speech and noise, that simultaneously determines the place and the stakes of politics as a form of experience. Through the description of singular events and their interplay with these entities I try to answer a set of related questions, in the different sections of this article: Who are these beings? What do their

\footnotetext{
${ }^{2}$ Melilla is a $12 \mathrm{~km} 2$ territory on the northern shores of Morocco's Alboran coast - the westernmost portion of the Mediterranean Sea. Together with Ceuta, they form the EU's only land borders with Africa. Melilla traces its Spanish past to the 15th century, along with other places by the North African coast that were turned into presidios, where prisoners performed the heavy manual labor of construction, repair and maintenance of fortifications and other military facilities (Pike, 1978, p. 22). In the second half of the 19th century, the enclave became a free port. Administratively, Melilla was part of the Province of Málaga until 1995, when it became an autonomous city.

As the narration unfolds, other footnotes will shed light on the specificities of the enclave, especially regarding migration issues.

${ }^{3}$ So far, I have never had the opportunity to build relationships of trust with women who have experienced border crossing, either around the enclave or on the Moroccan side where I only meet people through others (mainly men) who lead me to them. The same is true in Melilla, where the women mostly stay in the CETI. While the migrants in the CETI are allowed to leave, outsiders do not have access to the center. The women's choice to stay inside and only go outside occasionally in groups is probably explained by the lack of legitimacy for a woman to be in the public space, especially if she is alone and far from home. On how women experience border life, see Tysler (2018).

This research was carried out with the support of the French-Quebec research program MECMI: Morts en contexte de migration ANR-16-FRQC-0001.
} 
ordinary interactions look like? What narratives are told about the deaths in the desert, at sea, or near the fences? What do these narratives tell us about the ways in which migration endangers lives? And I conclude by exploring what happens to these beings and their interactions once they have left geopolitical borders behind them and finally find themselves in Europe. In doing so, my aim is to suggest that new forms of life are produced by the current border regime.

\section{Anonymous bodies}

Sitting on a rock, under the bridge near the Temporary holding center for migrants called CETI [Centro de Estancia Temporal para Inmigrantes], ${ }^{4}$ Naba Tigré, ${ }^{5}$ a 22 -year-old Bissa man from Burkina Faso, is eating a tiep poulet - a Senegalese dish of rice and chicken, cooked with vegetables - made by a woman from Niger in a pot on a gas stove installed just a few meters behind. He does not want to eat the food of the "campo" - the term border-crossers use to refer to the CETI, the shelter that houses adult migrants who have successfully entered the EU from Melilla as they wait to be sent to the Iberian Peninsula by the Spanish state. As Naba Tigré eats on this large rock, others further away are talking, smoking, and listening to music. All of a sudden, he receives a message on his mobile phone. A vessel has capsized while attempting to reach the Andalusian coast and two dead bodies have been recovered. These dead people suddenly burst into Naba's daily life, but this is no extraordinary occurrence. On the contrary, it is common for border-crossers to receive messages informing them that boats have disappeared, that dead bodies have been found, and that others are missing.

Naba calls a friend in Tangier - the vessel probably left from there. Yes, he already knows about the shipwreck. No, he does not know who made this attempt to cross the border. At the CETI, others have heard the news too. Everyone springs into action, contacting friends and acquaintances. They have to make sure their loved ones are not among the dead, but they must also help obtain information that could be useful in order to find out the identity of the deceased. All the people I met on both sides of the border told me stories about how they were able to connect a name with a body by using information gathered on the Internet. Smartphones are integral to all aspects of migrants' lives during their journey to Europe. Facebook, WhatsApp, and phone calls keep them informed about roads and opportunities (Diminescu, 2016), but they also make it possible to find or retain traces of the dead. Gathering information leading to the name of the deceased is the first step before being able to perform what all my interlocutors consider to be the essential "gesture" of announcing the person's death to his or her relatives. It is through Facebook, for example, that one of Naba Tigré's friends was able to reach the family of a young Malian who had died during an attempt to jump the fence and inform them of his fate.

Participating in efforts to identify unknown bodies and to reach the relatives is all the more important given that there is no specific procedure or protocol in place aimed at identifying the deceased and contacting the family, whether at a national or a European level. ${ }^{6}$ Naming the

\footnotetext{
${ }^{4}$ All unauthorized migrants over 18 arriving in the enclave of Melilla are sent to the CETI before being transferred to the Iberian Peninsula.

${ }^{5}$ All the names that appear in this article are fictitious. While this may seem counter to the motivations of my interlocutors, who, as it will become clear in the coming pages, are constantly fighting against anonymity, all of those who are still alive today are, at the time of writing, living undocumented somewhere in the EU, and I do not want to risk jeopardizing their chances of regularizing their administrative situation. As for the deceased mentioned specifically, I did not have the opportunity to contact their relatives and ask for their permission and so I prefer to avoid using their names also.

6 The lack of a standardized procedure to deal with these deaths may be considered what anthropologist Jason De León calls necroviolence, that is, "violence performed and produced through the specific treatment of corpses that is perceived to be offensive, sacrilegious, or inhumane by the perpetrator, the victim (and his or her cultural group), or both." $(2015$, p. 69). This postmortem corporeal mistreatment is reminiscent of the politics of "not caring about
} 
bodies found - whether via official identification (leading to the issuing of a death certificate) or simply informal recognition (allowing the family to be notified) - is something that depends on the goodwill of individuals and groups that contribute to finding or circulating information about the deceased.

For most of my interlocutors, contacting families in the event of death is a way of preventing the "total disappearance" of the deceased, which is how several border crossers described the material and symbolic obliteration that results from disappearing without a trace (Kobelinsky, 2017). Announcing the death makes it possible to deal with the dead. Even in the absence of a body, it is a way of restoring some form of traceability to the dead. Even if the family does not know the final location of the remains, at least they know that their loved one has died and that this death occurred in a particular place at a particular moment. The person's itinerary and story can then be (partially) retraced. The (symbolic) return of the deceased to the family enables his or her reintegration into a group of belonging, a genealogy. Even when the body is not repatriated, the deceased is somehow "reterritorialized" (Delaplace, 2015) as he or she is brought back among his or her own. Informing the relatives allows them to continue living their lives, as they are able to give a place and a status to their missing loved one. At the same time, this operation can also be understood as a way of mitigating the invisibility of border deaths in broader terms.

Many individual and collective practices have been developed to prevent total disappearance. Even when physical disappearance itself is inescapable, it remains possible to leave a trace in the memories of relatives and thus to prevent anonymity after death. There will at least be a loved one to mourn the deceased. Naba Tigré asked a fellow Bissa man from a village neighboring his own, with whom he had travelled for more than a year, to learn his mother's phone number by heart, in case he ever needed to announce Naba's death:

"I don't want to die but if I die, I will have tried and I want my family to know it. I want them to know that I did everything to move forward in life. I told my brother that if something happens to me, he has to call, he has to tell them that I did everything I could not to disappear completely" (conversation, April 17, 2016).

For Naba Tigré, he had embarked on migration precisely in order to avoid fading away and leaving no trace. He had left in order to become "somebody" and his biggest fear was falling into complete anonymity. ${ }^{7}$

\section{The Living dead}

On the supermarket parking lot, located about 15 minutes from CETI, young migrants stand by the supermarket entrance, where they hope to earn a few euros pushing the carts containing the customers' groceries. They spend a long time chatting. This April afternoon, Abou Coulibaly is triumphant. This 22-year-old Malian from Bamako is happy as he has obtained his "salida"

nor caring for" noncitizens in the United States, described as the "necropolitics of uncare" by Jonathan Inda (this volume).

${ }^{7}$ My interlocutors often use the term "somebody" to refer to their desire to be known, to be someone who is respectable and respected by their peers at home, through various means (whether by accumulating wealth or succeeding in the music industry, in football, etc.). Becoming "somebody" is contrasted with the shame of being "nobody", as many express it. It is this hope of reinventing themselves that border-crossers highlight in their narratives when they explain why they accept to risk their own lives. They all say they want to escape from a life "without anything", a life they perceive as lost and anonymous. My interlocutors accept the risk of dying rather than enduring the risk of being "nobody". Simply put, the idea behind this is that risk reaps reward. The reward is becoming "somebody" who will leave a trace in his time, among his peers and family at home.

${ }^{8}$ Meaning "exit", the term salida is employed both by CETI personnel and migrants to refer to the decision to send the person to the Iberian Peninsula. 
and will be leaving the enclave on Wednesday night. He will be sent by the Spanish state, with other border crossers, to the Iberian Peninsula where they will be looked after by NGOs for a while. ${ }^{9}$ As the store is quiet, indeed almost empty, Abou Coulibaly walks away from the automatic doors - next to which he was waiting for customers to leave - and comes to sit a meter away, near Boubou Kanouté, a young Mauritanian with whom I was talking. He expresses his joy and shares his plans for when he reaches "big Europe". He wants to come to France "as soon as possible"; this has been his goal since he left home more than a year ago. He continues by remembering his crossing:

Everything we've done to get to Europe, to find ourselves [se chercher]... I saw people die in the water the first time I tried to cross, two men, one skinny, he looked fragile, he didn't survive the conditions. [A few months later] I saw two women die in Morocco, one of them was pregnant. I did three months on the Gurugu, there you see the living dead [morts-vivants]. When I got there, I saw this, just living dead people, who eat scraps from the garbage, who sleep in the bushes in unimaginable conditions... (field notes, 04/11/2016)

In his account, Abou Coulibaly enumerates the deaths he witnessed during his journey. No one comments — not Boubou, not Masséré Diakité, a Soninke man from the Kayes region (Mali) who is standing next to him, not myself. The supermarket doors suddenly open, a man walks out with an overloaded cart. Abou Coulibaly rises quickly to go to him, but the man signals to him to stop and not to bother him. Boubou Kanouté then speaks up to complain about how the lunch in the canteen has given him a stomach ache and all three laugh at the questionable quality of meals at the "campo". Stories about death are usually incorporated into ordinary conversations, as though death were now part of their daily lives.

Abou Coulibaly's death list interestingly includes the "living dead" he met while staying in the precarious camps that have developed on the Gurugu mountain, only a few kilometers away from the enclave: a space where everyday life takes place until a successful border crossing is achieved and where people train themselves physically to increase their chances of success (Kobelinsky, 2019). Although they are not biologically dead, these beings are not considered fully alive either. Many of my interlocutors used the expression "living dead" to describe their daily lives in Morocco, on their way to Europe.

"Since getting to the Gurugu, I've understood; the first day I was watching everything, every movement, and I realized that the Gurugu is the cemetery. There is no life on the Gurugu, all the people are living dead [silence] because they are not respected, they are rejected by society, they are beaten and abused [by the "Moroccan military"], they do not live in society, they are in the bushes, in the forest, among the evil spirits. They eat leftovers. Only God protects them [...] They are not afraid to die because they are almost dead [...] I wasn't afraid of death, every time I tried to hit the fence, I said it was a way of being alive, that I was trying my luck for life" (interview 11/08/2014).

Gaoussou Dembélé, a 28-year-old from Mali, considered that the living conditions on the Gurugu mountain, as well as the general rejection of the locals and the treatment by law enforcement, turned him into one of the "living dead" whose life was reduced to mere survival. The various accounts I collected about the "living dead" all emphasized that while their bodies were still alive, they were devoid of subjectivity. Narratives about these shattered lives also insist on the superfluity of their being. To use Judith Butler's terms, someone who already understands himself "to be a dispensable sort of being, one who registers at an affective and

\footnotetext{
${ }^{9}$ Once on the other side of the Mediterranean Sea, they can be confined in a detention facility in order to organize their deportation from the national territory or they can be hosted by an NGO providing health, social, and legal aid for some months. The type of care they receive varies according to the NGO. Migrants can thus find themselves in collective shelters or in apartments shared with 4, 6, or 10 people. In all cases, this provision is currently scheduled for a three-month period, renewable once.
} 
corporeal level that his life is not worth safeguarding, protecting and valuing." (2012, p. 10). Someone who would not be grieved if he were really dead.

The "ungrievability" that seems to be experienced by Gaoussou Dembélé and many others echoes their sense of living an unworthy life, a sentiment already present before they engaged in border crossing. The difficult living conditions in the camp on the Gurugu Mountain, as well as in squats and other precarious places where they stay during their journey to Europe, generate both specific experiences of deprivation and a self-perception of social invisibility that, for some of the interlocutors, had already served as the initial impetus for their migration (Timera, 2001, 2009; Graw, 2012). In short, these conditions replicate everything they were struggling to leave behind through migration. Together, extreme vulnerability and social abandonment turn the living dead into beings with a "bare life" that is not natural life per se (Agamben, 1998) but rather a life exposed to border violence and to death. In this sense, the living dead of the border echo the living dead of the African postcolony depicted by the philosopher Achille Mbembe (2001): those who live in death, who are already dead "while having not necessarily left the world or being part of the spectre" (ibidem, p. 202).

\section{The disappeared}

Sitting away from the sun that is beating down hard on this May afternoon (2016), not far from the road, at the bottom of the mountain, Fodé Yattara, a 22-year-old Guinean, talks about his multiple attempts to scale the fences. "Every time we try, life is at stake, brothers have died at the fences and no one knows anything about them, they vanish as though they were eaten up by the mud". His friend, whose name escapes me, has been silent since we met for the first time an hour or so before. He then adds "the dead simply disappear".

The fences Fodé Yattara is referring to are an important element of the Spanish-Moroccan rebordering (Ferrer Gallardo, 2008) that began to develop all along the $12 \mathrm{~km}$ border between Melilla and Morocco after Spain joined the EU in order to prevent migrants from trying to cross the border irregularly. ${ }^{10}$

Many stories like Fodé's, about the deaths that occur during each attempt to scale the fences and the disappearance of these bodies, have been circulating around the enclave for years. The

\footnotetext{
${ }^{10}$ The construction of a fence all along the $12 \mathrm{~km}$ border between Melilla and Morocco began in 1998. At the time, it was one single fence. Subsequently, a second three-meter high barrier was also built in parallel to the first. In 2005, as a response to several attempts by border-crossers to jump the double fence - described in the media as "crisis de las vallas" [the crisis of the fences] — the government decided to raise the fences in question to six meters and build a three-dimensional rope, known as the third fence, aimed at preventing any passage between the first and second barrier (APDHA, 2014). During the 2005 attempts, bullets fired from both sides of the border killed at least eleven people and injured hundreds of others (Migreurop, 2006). Barbed wire can be found all along the border and a sophisticated network of underground cables is linked to electronic noise and motion sensors. This surveillance is completed by night vision video cameras and increased numbers of law enforcement agents from the Gendarmerie royale marocaine and the Guardia Civil constantly patrolling the border. From 2006 onwards, this time in order to respond to what the Spanish media called the "cayucos crisis", the new "Africa Plan" led to agreements being signed with some of the countries that are the point of departure for the boats, i.e. Senegal and Mauritania, so as to reinforce border control cooperation (APDHA, 2007). The crossing of the border at Melilla mainly takes place by land, unlike the strategies developed by border-crossers trying to reach Ceuta, which combine attempts to cross by sea with attempts to scale the fences. In 2015, in the context of the war in Syria and the so-called "refugee crisis" in Europe, Spain opened an Office to handle asylum claims at the borders in Melilla and Ceuta. At the same time, the Guardia Civil reinforced its surveillance deploying 600 officers in Melilla alone and a rotating unit of 180 guards exclusively dedicated to border surveillance (Migreurop \& Gadem, 2015, p. 3). As for Morocco, it has dug a ditch between the first fence and the road in strategic border zones (APDHA, 2016, p. 53).
} 
narratives I collected ${ }^{11}$ all agreed on the cause of death: these migrants died in confrontations, at the fence, with the Moroccan gendarmerie and the Spanish Guardia Civil. However, when it comes to explaining the disappearance of these bodies that nobody can trace, the story itself fades away and is replaced by a whole range of hypotheses: the bodies are perhaps swallowed by the Earth, eaten by dogs, or buried in secret mass graves (Kobelinsky, 2017). And talking with some of my interlocutors whom I first met at the border but then saw again, once on the European mainland, another possibility emerged: that of organ trafficking.

These rumors are not very reassuring. On the contrary, they contribute to shaping a daily world full of uncertainty (Bonhomme, 2009): uncertainty about the possibility of dying; uncertainty about the probability of succeeding in crossing the border. They reveal the anxieties of this particular place (White, 2000, p. 83), where law enforcement is overwhelmingly present. These stories draw on the proven brutality of the management of migrants at the border and put into words the violence of Moroccan and Spanish law enforcement agencies. Although distressing, these narratives also make the absent present. "Maybe we tell them so as to remember the dead?" wondered Cellou Diallo, a Fulani man from Guinea, in a discussion about the stories he had heard since coming to Morocco and that he, in turn, helped pass on to anyone who wished to collect them.

By remembering those who are absent, the key importance of their disappearance also emerges. In fact, in the narratives I assembled, border-crossers do not seem to fear death the most, but rather disappearance. This is a distinction I found in many of my interlocutors' narratives about their experiences and should be related to their self-perception of social invisibility. By disappearing at the border, they would become definitively invisible: anonymous bodies with no genealogical ties, cut off from their families, leaving no trace, and therefore "ungrievable". As already noted, it is precisely this (social) invisibility that they are trying to escape through migration. The stories turn individual fears into a collective or even political issue, as the fence itself is what brings about these disappearances. Cognitive and pragmatic skills have been attributed to the fence, which takes on a life of its own and acquires a deadly agency. ${ }^{12}$ Disappearance looms for all my interlocutors as the haunted horizon established by the violence of the contemporary border regime.

\section{Ghosts}

Ibrahim Camara, a young Fulani man from Guinea, spent some weeks working at the entrance of the supermarket before he had a fight with the "boss", a fellow migrant in charge of the cart business with the collusion of the security guards and the store manager, and so had to leave the parking lot where I met him. During a long walk "to kill time", now that the supermarket opening hours were no longer determining the rhythm of his days, I told Ibrahim about my particular research interest in death at the borders. He laughed and shouted out: "You've got it! We live with the dead of the journey!". He then told me that he was in Melilla thanks to a dead person. Ibrahim was convinced that it was Alhassane Diallo who helped him scale the fences. In a dream, this 20-year-old Guinean had told him "Petit, you'll give it everything in the next strike and it will be Boza" [the victory cry when crossing successfully]. With a big smile on his face, Ibrahim added: "He was right, I thought about him, I was so focused, I didn't let go, and I hit the ground in Melilla, I ran with all my strength, he gave me strength, and he protected

\footnotetext{
${ }^{11}$ These narratives were not only collected from migrants discussing border crossing, but also from activists and people working on institutions dealing with migrants in Melilla and Nador.

12 This question of the life and actions of human-generated technologies is clearly illustrated by Bruno Latour's example of the shepherd who installs a fence that prevents his sheep from escaping. The fence becomes an actor that is fully part of the social world of both the shepherd and his sheep (Latour, 1994).
} 
me." He had never dreamed about Alhassane before. All the time, he remembered Alhassane, whom he had seen die in the desert in Niger, as well as his body, which he had had to leave behind. Alhassane Diallo's death had been very hard to bear and had prevented him from sleeping, but his person had never appeared in his dreams or in his nightmares. And then, all of a sudden, almost a year after his death, Alhassane was present once again and giving him a clear message. Ibrahim took over from his deceased comrade and succeeded in crossing the border in his stead. In so doing, Ibrahim "prolonged" his friend's existence; he "accomplished" him (Despret, 2015, pp. 88-89).

Since this single apparition, Alhassane has not come back. Ibrahim waited for his comrade in his dreams but, as he put it, "I think he does not want to come, or he has nothing to say to me". While Alhassane Diallo does not appear anymore, other dead people are present more regularly and even accompany the living in their lives at the border. Mamadou Diawara is "more or less accompanied" by a "petit" whose name he does not know, who drowned in a shared attempt to cross the Mediterranean in a small boat. The little boy appears unexpectedly but frequently in Mamadou's daily life. Mamadou feels his presence and while they do not talk to one another, he knows that the petit is watching him. He may be an "ontological refugee", to use the expression coined by anthropologist Hoenik Kwon (2008, p.16), who speaks of these unburied wanderers who cannot be fixed either in the world of the dead or in the world of the living.

I am not interested here in discussing belief in these apparitions, but rather in exploring what they might reveal (see Claverie, 2003). Ghostly apparitions and dreams in which the deceased achieves something both affect those who experience them and this has consequences on their lives (see Delaplace, 2018). The apparitions are invoked as figures of return or revenants - like the ghosts described by Esther Pereen (2014) in her study on spectralities - capable of expressing the persistence of the past in the present. And this present absence points to the fact that "there is something there that matters and has to be taken into account" (Pereen, 2014, p. 10). The apparition of the petit makes a painful story visible: that of his death but probably also that of the ordeal of border crossing as experienced by Mamadou Diawara. This appearance probably possesses other functions and meanings too, although they lie beyond the scope of my inquiry here. What does seem clear, however, is that border dead are present and that they bring to the fore things that are not always "sayable".

These apparitions, along with stories about those who have disappeared, the struggles of the living dead, and the ways in which border-crossers deal with the news of a lifeless body found somewhere or other, bring out the private and ordinary dimensions of border violence: how border-crossers live with the dead. This cohabitation takes place at the intersection of the visible and the invisible, of what is "sayable" and what is not, and therefore traces the contours of border politics as experienced - and sometimes embodied - by those it targets.

\section{Taming ubiquity and resisting invasion}

Cultures have different beliefs about death and dying; in some, life is not considered to end with biological death. Although my interlocutors belong to a diverse range of groups and cultures, all of them share a conception in which there is no binary distinction between life and death, just as there is no clear separation between the world of the living and that of the dead. Furthermore, for them death is a part of life and many entities exist that are neither alive nor dead. When discussing the lives of my interlocutors back home, we also talked about the apparition of dead persons - one interlocutor, for instance, lived next door to an old woman to whom the dead, appeared regularly — but also djinnis — a friend I met during fieldwork was himself inhabited by a djinni as a child. 
On the migrant trail to Europe, border-crossers live surrounded by stories about disappeared comrades and drowned friends; they intermingle on a daily basis with the living dead, with ghosts, and with anonymous bodies. Some of these beings can also echo modalities of presence and existence that have long prevailed in the worlds of the people I encountered. At the border, this profusion of beings and stories contributes to creating a communauté de destin that allows painful experiences to be shared. ${ }^{13}$ Talking about these border beings affords the possibility of collective mourning or at least makes it possible to tame the pervasiveness of death and to handle the management of the dead.

I wonder, however, what happens to these narratives once these border-crossers have left the geopolitical border behind them. What remains of those who have died or disappeared in the lives of those who successfully reach Spain, France, or Germany? Although I do not have enough ethnographic material to answer this question precisely and accurately, many of the practices and narratives I have collected from the interlocutors whose itineraries I have been able to follow from Melilla/Morocco to the Iberian Peninsula, France, or Germany, make me think that there is still a form of life with the dead. I will limit myself to pointing to a few potential avenues in this regard.

For some of my interlocutors, the acknowledged ubiquity of death at the border becomes a trauma once they are in Europe. "I want to get rid of all this, I don't want to remember, I want to not know", a young man from Burkina Faso confided to me in a conversation after a long day of work in the Andalusian greenhouses. "I try to think only of the vegetables, the eggplants, but all these black thoughts come up". Naba Tigré - also Burkinabe, whose trajectory I followed for three years from the enclave to Germany and back to Spain- likewise made reference to his memories of border deaths as sudden and annoying thoughts of an intrusive nature. "Sometimes I think about the disappeared of the fence, it's all madness. It comes back to me, it comes back to me". Both of them told me that they don't talk much about border deaths and that they try to forget, "just to move on". These statements are in line with what I have been told, in informal conversations, by social workers and researchers working with migrants who have recently arrived in Europe, for whom it is very difficult to talk about the people who died during border crossing. The issue is either avoided or very vaguely mentioned, in a fragmentary fashion.

The determination to forget or the refusal to talk about it does not mean, in my view, that the effects of the border regime's violence are fading. One could put forward the hypothesis that this silence relates to the annihilating nature of trauma, which may well have destroyed the capacity to communicate. Pain may resist language (Scarry, 1985). It is also possible that these memories are only shared with people who have had the same experiences.

However, while some migrants fight against intrusive thoughts relating to border deaths and border beings, others seem to find a sort of peaceful cohabitation with them. "Le petit is part of me", admitted Mamadou Diawara, as he sat drinking juice in a small square in a city near Paris. The little boy who had appeared in his life at the border was also with him in Malaga (Spain) and now in France. His ghostly presence was voiceless but "it's better like this, so he does not tire me out!" jokes Mamadou, who seems to have adopted the boy, or at least his ghostly presence, as a new member of his family.

The forms of suffering and dying at the core of the border beings I have presented here are not moments of crisis. Rather, they are ordinary, and even chronic. At the border, they acquire a presence that informs the lives of the people I met. Even once the migrants have left the fences

\footnotetext{
${ }^{13}$ This resonates with the way in which the intimate experiences of gender violence can only be shared in spaces dedicated to this, as María Martínez shows in this volume.
} 
far behind them, they seem to continue to live their lives along with border deaths and border beings, whether these are normalized, passed over in silence, resisted, or prove hard to overcome. The effects of border politics are still felt in the heart of Europe.

The last I heard, Alhassane had not reappeared in Ibrahim Camara's dreams, but, as he told me by phone from Germany, Alhassane is still an everyday presence for him: "He is always with me." And indeed, every time Ibrahim recounts the day he got to Europe, he invokes his dead companion. In telling his story, Ibrahim also speaks both of the lives lost and the afterlives produced by border politics, all of which are now an intrinsic part of his very being.

\section{References}

Agamben, G. (1998). Homo Sacer: Sovereign Power and Bare Life. Stanford: Stanford University Press.

Albahari, M. (2015). Crimes of Peace. Mediterranean Migrations at the World's Deadliest Border. Philadelphia: University of Pennsylvania Press.

APDHA (2016). Derechos humanos en la frontera sur, Sevilla, Asociación Pro Derechos Humanos de Andalucía. URL: http://www.apdha.org/media/informe-frontera-sur-2016web.pdf [accessed on 06/27/2018].

APDHA (2014). Derechos humanos en la frontera sur, Sevilla, Asociación Pro Derechos Humanos de Andalucía. URL: http://www.apdha.org/media/frontera_sur_2014_web.pdf [accessed on 06/27/2018].

Babels (2017). La mort aux frontières de l'Europe : retrouver, identifier, commémorer. Neuvyen-Champagne : Le passager clandestin.

Bonhomme, J. (2009). Les Voleurs de sexe. Anthropologie d'une rumeur africaine. Paris : Seuil.

Butler, J. (2006[2004]). Precarious Life. The Powers of Mourning and Violence. New York : Verso.

Claverie, E. (2003). Les guerres de la vierge. Une anthropologie des apparitions. Paris: Gallimard.

Das, V. (1995). Critical events: an anthropological perspective on contemporary India. Delhi: Oxford University Press.

Delaplace, G. (2009). L'invention des morts. Sépultures, fantômes et photographies en Mongolie contemporaine. Paris : Centre d'études mongoles et sibériennes- Ecole pratique des hautes études.

Delaplace, G. (2018). Les fantômes sont des choses qui arrivent. Surgissement des morts et apparitions spectrales. Terrain, 69, 4-23.

De León, J. (2015). The Land of Open Graves. Living and Dying on the Migrant Trail. Oakland, CA: University of California Press.

Despret, V. (2015). Au bonheur des morts. Récits de ceux qui restent. Paris : La Découverte.

Diminescu, D. (2016). Traces numériques. Plein droit, 110(3), 3-6.

Ferrer Gallardo, X. (2008). The Spanish-Moroccan Border Complex: Processes of Geopolitical, Functional and Symbolic Rebordering. Political Geography, 27, 301-321. 
Foucault, M. (1978). The History of Sexuality. Volume 1. The Will to Know. New York: Pantheon Books.

Foucault, M. (2009). Security, Territory, Population. Lectures at the Collège de France 19771978. Paris: Picador.

Foucault, M. (2010). The Birth of Biopolitics. Lectures at the Collège de France 1978-1979. Paris: Picador.

Graw, K. (2012). On the cause of migration: Being and nothingness in the African-European border zone. In K. Graw \& S. Shielke (Eds). Global Horizon: Expectations of Migration in Africa and the Middle East (pp. 23-42). Leuven: Leuven University Press.

Kobelinsky, C. (2017). Exister au risque de disparaitre. Récits sur la mort pendant la traversée vers l'Europe. Revue européenne des migrations internationales, 33(2-3), 115-131.

Kobelinsky, C. (2019). Des traces anonymes. Le traitement des morts aux frontières hispanomarocaines. Critique internationale, 83(2), 21-39.

Kwon, H. (2008). Ghosts of war in Vietnam. Cambridge, UK: Cambridge University Press.

Latour, B. (1994). Une sociologie sans objet? Note théorique sur l'interobjectivité, Sociologie du travail, 36(4), 587-607.

Mbembe, A. (2001). On the Postcolony. Berkeley, CA: University of California Press.

Mbembe, A. (2003). Necropolitics, Public Culture, 15(1), 11-40.

Migreurop. (2006). Guerre aux migrants. Le livre noir de Ceuta et Melilla. Migreurop. http://www.migreurop.org/IMG/pdf/livre_noir_ceuta_et_melilla.pdf

Migreurop \& Gadem (2015). Gérer la frontière euro-africaine. Melilla, laboratoire de l'externalisation des frontières de l'Union européenne en Afrique, Migreurop, URL : http://www.migreurop.org/IMG/pdf/fr_note_melilla_2015-2.pdf

Pereen, E. (2014). The Spectral Metaphor. Living Ghosts and the Agency of Invisibility. Basingstoke: Palgrave Macmillan.

Pike, R. (1978). Penal Servitude in the Spanish Empire: Presidio Labor in the Eighteenth Century, The Hispanic American Historical Review, 58(1), 21-40.

Rancière, J. (2004). The Politics of Aesthetics. The Distribution of the Sensible. London \& New York: Continuum Impacts.

Rygiel, K. (2016). Dying to live: Migrant deaths and citizenship politics along European borders: Transgressions, disruptions and mobilizations. Citizenship Studies, 20(5), 545-560.

Scarry, E. (1985). The body in pain. The making and unmaking of the world. New York \& Oxford: Oxford University Press.

Squire, V. (2016). Governing Migration Through Death in Europe and the US. Identification, Burial and the Crisis of Modern Humanism. European Journal of International Relations, 23(3), 513-532.

Tassin, E. (2010). Clandestinité et visibilité. Des disparus en régime libéral. In H. Bentouhami \& C. Miqueu (Eds.). Conflits et démocratie. Quel nouvel espace public ? (pp. 41-54). Paris : La Découverte.

Timera, M. (2001). Les migrations des jeunes sahéliens : affirmation de soi et émancipation, Autrepart, 18(2), pp. 37-49. 
Timera, M. (2009). Aventuriers ou orphelins de la migration internationale ? Nouveaux et anciens migrants "subsahariens" au Maroc. Politique africaine, 115, 175-195.

Topak, O. (2014). The biopolitical border in practice: Surveillance and death at the GreekTurkey borderzone. Society and Space, 32, 815-833.

Tysler, E. (2018). 'Boza !' disent aussi les femmes. Vacarme, 83, 82- 91.

Weber, L. \& Pickering, S. (2011). Globalization and Borders: Death at the Global Frontier. Basingstoke \& New-York: Palgrave Macmillan.

White, L. (2000). Speaking with Vampires. Rumor and History in Colonial Africa. Berkeley, CA: University of California Press. 